International Journal of Health Sciences
Available online at www.sciencescholar.us
Vol. 5 No. 3, December 2021, pages: 302-312
e-ISSN: 2550-696X, p-ISSN: 2550-6978
https://doi.org/10.53730/ijhs.v5n3.1512

\title{
Ecological Situation: The Role of Education and Spirituality in Improving Health of Population
}

\author{
CrossMark \\ Nilufar K. Komilova a, Tura Rakhimova ${ }^{b}$, Rustamjon Kh. Allaberdiev c, Gulnara S. Mirzaeva d, \\ Umriniso T. Egamberdiyeva ${ }^{\mathrm{e}}$
}

Manuscript submitted: 18 May 2021, Manuscript revised: 09 August 2021, Accepted for publication: 17 September 2021

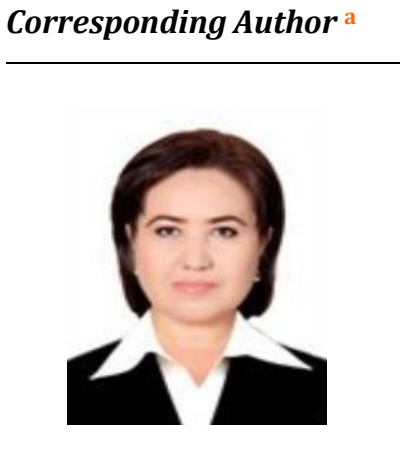

Keywords

environmental factors;

health sector;

healthy generation;

industrial cities;

infant and maternal;

medical geography;

mortality;

\begin{abstract}
Human health is one of the most important issues for every period of society's development. After all, the state of development of any country is determined by the level of health and literacy of the population living in the region. The article highlights the ecological situation, the role of knowledge and spirituality in strengthening the health of the population in Uzbekistan, the achievements of medicine, ecology, socio-demographic development in the country during the years of independence data on the reduction of infant and maternal mortality in the age group of the population are also presented. It is known that in more than a quarter of a century (1991-2019), the total mortality rate in the country's population decreased by $1.2 \%$ or decreased from 6.2 per thousand to 4.9 per thousand. However, there are still areas with high mortality rates (in Tashkent, Tashkent, and Andijan regions), which can be explained by their location at the transport hub and industrialization. The study and analysis of their regional aspects are some of the important aspects of geographical research. The article also focuses on the issues related to climate change and their impact on the nosoecological situation.
\end{abstract}

International Journal of Health Sciences (C) 2021.

This is an open access article under the CC BY-NC-ND license (https://creativecommons.org/licenses/by-nc-nd/4.0/).

\section{Contents}

Abstract

1 Introduction

Dynamics of Infant and Maternal Mortality in the Republic of Uzbekistan

3 Nosogeographic Situation in the Republic of Uzbekistan.

${ }^{a}$ National University of Uzbekistan named after Mirzo Ulugbek, Tashkent, Republic of Uzbekistan \& Gulistan State University, Gulistan, Republic of Uzbekistan

${ }^{\text {b }}$ National University of Uzbekistan named after Mirzo Ulugbek, Tashkent, Republic of Uzbekistan

${ }^{c}$ National University of Uzbekistan named after Mirzo Ulugbek, Tashkent, Republic of Uzbekistan

d Institute of Zoology of the Academy of Sciences of the Republic of Uzbekistan, Tashkent, Republic of Uzbekistan

e National University of Uzbekistan named after Mirzo Ulugbek, Tashkent, Republic of Uzbekistan 


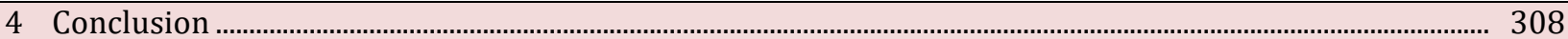

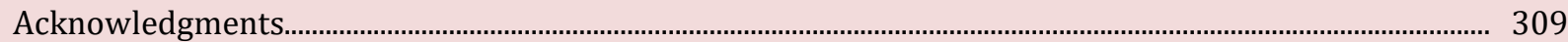

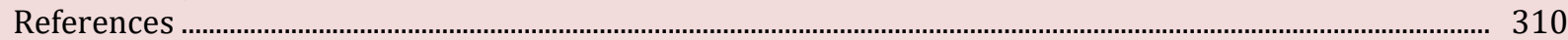

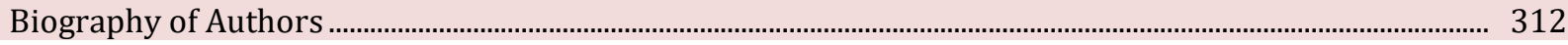

\section{Introduction}

In the context of globalization and sharp competition, the steady growth of the population, the incidence of infectious and non-communicable diseases among the population are growing, and international organizations are paying great attention to combating these problems. In particular, the United Nation (UN) Sustainable Development Program until 2030 emphasizes "the elimination of epidemics of diseases such as tuberculosis, malaria, as well as measures to combat hepatitis and other water-borne diseases by 2030" (United Nation, 2021). Implementation of these tasks requires stabilization of the nosoecological situation in arid climates.

Many measures are being taken in the country to further strengthen the health of the population, modernize the health sector, reduce the number of groups and types of diseases, protect motherhood and childhood. Clause 4 of the "Strategy for further development of the Republic of Uzbekistan for 2017-2021" states: "ta'minlash Ensuring a reduction in morbidity and life expectancy among the population; the health sector, first of all, is aimed at improving the convenience and quality of medical and socio-medical services to the population" (On the Strategy..., 2017; Palmer, 2018). As a clear example of the attention paid to the health and protection of the population in Uzbekistan during the years of independence, in particular, the Year of Healthy Generation in 2000, the Year of Health in 2005, the Year of Sponsors and Doctors in 2006, the Year of Healthy Child in 2016, 2016 The Year of Healthy Mother and Child can be seen in the fact that 2021 is marked as the Year of Youth Support and Public Health.

This name of the current year is an important historical event, which serves as a program for the training of highly spiritual and environmentally friendly personnel. Today in the country it is important to improve the health of the population, a healthy lifestyle in society, and the health of the population, especially maternal and child health. In recent years, the country has given priority to maternal and child health, spiritual and educational upbringing of the younger generation, social protection, and improving its quality. Some targeted national programs to strengthen the reproductive health of the population, protection of motherhood and childhood are being implemented in the country (Nodir, 2020). As a result, "between 1991 and 2019, the overall mortality rate decreased by $20 \%$, and maternal and infant mortality by 3.1 times. Life expectancy has increased by 4.6 years compared to 1995 and now stands at 73.7 years. During this period, especially in the districts of Khorezm and Surkhandarya regions, there was a decrease in infant mortality compared to other regions" (Komilova et al., 2019).

\section{Dynamics of Infant and Maternal Mortality in the Republic of Uzbekistan}

According to the analysis of the dynamics of maternal mortality in the country, it can be seen that from 1995 to 2020 there was a slight decrease (Boyle \& Ferlay, 2005). This was a sharp decline in 1995 to 32.2 per 100 000 live births, compared to 21.0 in 2010. In 2020, the figure was 18.5. The severity of changes in the dynamics of maternal mortality occurs mainly in a situation that is partially related to the birth and marriage processes. It should be noted that it is precisely when the number of marriages increases that there is a high probability of changes in maternal mortality in the year following the marriage period (Brown et al., 2021). In Uzbekistan, special attention is paid to women, women's clinics, examinations of women of reproductive age are always under control. Even under such conditions, the observation of maternal and infant mortality faces problems related to the environmental situation. In 2020 Komilova et al. (2020c), the highest maternal mortality rate in the country was 18.5 per 100000 live births, with Navoi, Tashkent, and Jizzakh regions (Table 1) (State Committee..., 2021). When analyzing the causes of maternal mortality about the

Komilova, N. K., Rakhimova, T., Allaberdiev, R. K., Mirzaeva, G. S., \& Egamberdiyeva, U. T. (2021). Ecological situation: the role of education and spirituality in improving health of population. International Journal of Health Sciences, 5(3), 302-312. https://doi.org/10.53730/ijhs.v5n3.1512 
environmental situation in the above regions, chronic anemia, gestosis, acute heart, and kidney failure diseases are relatively more common in mothers.

Table 1

Dynamics of maternal mortality in the Republic of Uzbekistan

\begin{tabular}{|c|c|c|c|c|c|c|c|}
\hline \multirow{2}{*}{ Regions } & \multicolumn{6}{|c|}{ Compared to 100000 live births } & \multirow[t]{2}{*}{$\begin{array}{c}\text { Changes } \\
\text { index }\end{array}$} \\
\hline & 1995 & 2000 & 2005 & 2010 & 2015 & 2020 & \\
\hline Republic of Uzbekistan & 32.2 & 33.1 & 29.2 & 21.0 & 18.9 & 18.5 & 0.57 \\
\hline \multicolumn{8}{|l|}{ The Republic of } \\
\hline Karakalpakstan & 50.5 & 38.8 & 15.4 & 26.4 & 29.0 & 30.5 & 0.60 \\
\hline Andijon & 32.0 & 20.2 & 21.0 & 18.3 & 12.9 & 14.7 & 0.45 \\
\hline Buxoro & 27.3 & 49.0 & 29.9 & 23.1 & 7.6 & 9.6 & 0.35 \\
\hline Jizzax & 30.0 & 29.4 & 24.8 & 27.0 & 25.1 & 13.1 & 0.43 \\
\hline Kashkadarya & 28.3 & 39.9 & 24.4 & 14.1 & 15.3 & 10.0 & 0.35 \\
\hline Navoi & 25.2 & 91.6 & 49.3 & 27.2 & 24.7 & 33.6 & 1.33 \\
\hline Namangan & 18.9 & 27.0 & 30.7 & 21.7 & 8.1 & 5.4 & 0.65 \\
\hline Samarkand & 38.4 & 26.4 & 17.4 & 16.0 & 21.4 & 9.9 & 0.25 \\
\hline Surxondaryo & 39.8 & 24.6 & 23.9 & 13.7 & 18.6 & 36.2 & 0.00 \\
\hline Sirdaryo & 29.7 & 21.0 & 34.8 & 12.3 & 5.6 & 38.0 & 1.27 \\
\hline Tashkent & 46.9 & 27.5 & 43.2 & 32.8 & 44.3 & 28.8 & 0.61 \\
\hline Fergana & 11.7 & 22.5 & 31.7 & 17.0 & 12.6 & 23.7 & 2.02 \\
\hline Khorezm & 25.4 & 24.9 & 41.5 & 30.6 & 15.2 & 11.9 & 0.46 \\
\hline Tashkent city & 55.6 & 63.9 & 44.6 & 25.4 & 25.7 & 20.0 & 0.35 \\
\hline
\end{tabular}

Another important achievement of the demographic situation in the country in recent years is a significant reduction in infant mortality (McAlister \& Baskett, 2006). If in 1995 the infant mortality rate was 26.0 per 1000 live births, in 2010 the figure was 11.0, and in 2020 it was 9.3. At the end of 2020, infant mortality in the country decreased compared to the first period of independence, but in Tashkent (12.7), Andijan (12.8) and Khorezm region (12.6) is much higher than the national level. In Navoi and Surkhandarya regions, the situation is slightly better than in previous years. Good health care in these areas and a special focus on family planning are contributing to the healthier generation of the younger generation. It is worth noting that while some regions are characterized by a decrease in infant mortality compared to 1995, in others the opposite is true. In the Aral Sea region, in the Republic of Karakalpakstan, Khorezm, and Andijan regions, the indicators are still negative (Table 2) (State Committee..., 2021). In general, infant mortality in the regions of the country is declining every year, but in some areas, such as Tashkent, Khorezm, Andijan, and the Republic of Karakalpakstan, it is particularly high. This is since the city of Tashkent and Andijan is the largest industrial and transport center of the country, and some of the above regions are located in the Aral Sea region, ie in the region with a negative nosoecological situation (Chang et al., 2020; Zhu et al., 2013).

Table 2

Dynamics of infant mortality in Uzbekistan

\begin{tabular}{|c|c|c|c|c|c|c|c|}
\hline \multirow{2}{*}{ Regions } & \multicolumn{6}{|c|}{ Compared to 1000 live births } & \multirow{2}{*}{$\begin{array}{l}\text { Phase } \\
\text { index }\end{array}$} \\
\hline & 1995 & 2000 & 2005 & 2010 & 2015 & 2020 & \\
\hline Republic of Uzbekistan & 26.0 & 18.9 & 14.9 & 11.0 & 11.4 & 9.3 & 0.35 \\
\hline $\begin{array}{l}\text { The Republic of } \\
\text { Karakalpakstan }\end{array}$ & 31.5 & 20.5 & 17.4 & 11.8 & 11.6 & 11.8 & 0.37 \\
\hline Andijon & 23.5 & 15.2 & 12.3 & 9.4 & 14.2 & 12.8 & 0.54 \\
\hline Buxoro & 21.0 & 19.0 & 12.0 & 11.3 & 10.0 & 7.4 & 0.35 \\
\hline Jizzax & 25.1 & 16.2 & 12.3 & 8.8 & 9.9 & 8.6 & 0.34 \\
\hline Navoi & 28.1 & 18.4 & 10.9 & 6.6 & 9.8 & 7.4 & 0.26 \\
\hline
\end{tabular}




\begin{tabular}{lccccccc}
\hline Namangan & 26.8 & 18.8 & 15.1 & 12.5 & 12.2 & 10.6 & 0.39 \\
Samarkand & 24.2 & 16.0 & 12.7 & 9.4 & 10.1 & 6.5 & 0.26 \\
Surxondaryo & 29.5 & 20.7 & 11.6 & 7.8 & 9.9 & 8.6 & 0.29 \\
Sirdaryo & 23.1 & 20.4 & 16.7 & 10.2 & 12.9 & 9.6 & 0.41 \\
Tashkent & 24.6 & 19.6 & 15.4 & 11.0 & 10.9 & 10.7 & 0.43 \\
Fergana & 27.3 & 19.3 & 19.3 & 14.1 & 9.1 & 6.6 & 0.24 \\
Khorezm & 25.9 & 24.6 & 16.3 & 12.0 & 14.2 & 12.6 & 0.48 \\
Kashkadarya & 24.0 & 19.0 & 13.8 & 10.1 & 8.6 & 7.8 & 0.32 \\
Tashkent city & 31.3 & 19.5 & 22.3 & 17.1 & 19.9 & 12.7 & 0.40 \\
\hline
\end{tabular}

\section{Nosogeographic Situation in the Republic of Uzbekistan}

In Uzbekistan, $57 \%$ of deaths among children under the age of five occur in the neonatal period, ie in the first 28 days of life. Statistical analysis shows that among the causes of death are: premature birth, asphyxia. There are three main causes, such as infections. Mortality from respiratory diseases, diseases of the gastrointestinal tract, cardiovascular system, chronic liver disease, diseases of the ENT (ear, nose, throat) organs, infectious diseases are also common in young children. The following recommendations have been developed to reduce and prevent infant mortality:

a) increase women's employment in these areas;

b) provision of pediatricians and gynecologists in these areas;

c) prevention of salt and dust storms and prevention of the population, especially children, pregnant women, and the elderly;

d) improving the medical examination of pregnant and women of childbearing age.

Under the influence of various ecological, negative anthropogenic factors of the Republic, the number of negative ecological factors affecting the medical geographical situation, the environment, the human body is increasing. It plays an important role in ensuring sustainable development, i.e. the health of the next generation (Falciglia et al., 2020; Robinson, 2004). The health of mothers is extremely important in the health of the next generation. For this reason, authors have developed a system of factors that affect maternal and child health. It consists of: personality activity, environmental factors, attitudes of family and others, social environment, etc. At the same time, it should be noted that there are still unresolved issues in improving the health of the population in the country (Humpel et al., 2002; Clayton \& McKeigue, 2001). For example, today in the country, maternal and infant mortality, some disease groups (respiratory, malignant tumors, nervous system, etc.) are declining, but among the population there are blood and blood-forming organs, heart, stroke, accidents and poisonings, groups of diseases related to the digestive system are increasing. In medical geographical research, the analysis of regions in terms of nosogeographic situation is of great importance (McLeod, 2000).

Climate change is the most significant challenge of the twenty-first century with the potential to cause significant human and economic damage (Stern, 2006). The 21st Conference of the Parties to the United Nations Framework Convention on Climate Change, held in Paris in December 2015, saw a commitment by states to keep the increase in temperature to no more than $2^{\circ} \mathrm{C}$ compared to preindustrial levels and to attempt to limit the increase to $1.5^{\circ} \mathrm{C}$. Even if this is achieved, significant changes are likely to occur, posing increasing threats to communities and infrastructure (Taylor et al., 2013; Fedakar et al., 2007). Nosogeographic situation is primarily characterized by the mortality rate of the population in a particular place or area, life expectancy, general morbidity, the presence of foci or areas of disease. As an extremely delicate, influential territorial system, it is highly variable as it depends on various natural and socio-economic factors (Figure 1). The ecological and demographic conditions of the places also have an impact on the nosogeographic situation Territorial complexes play an important role in geography. A comprehensive approach to this science, the identification of different regional systems, regional structures, and regional complexes are among the important methodological issues. In this regard, the study of such complexes is also

Komilova, N. K., Rakhimova, T., Allaberdiev, R. K., Mirzaeva, G. S., \& Egamberdiyeva, U. T. (2021). Ecological situation: the role of education and spirituality in improving health of population. International Journal of Health Sciences, 5(3), 302-312. https://doi.org/10.53730/ijhs.v5n3.1512 
required in the geography of human diseases - nosogeography (Komilova, 2021; Komilova et al., 2020a; Komilova et al., 2020b).

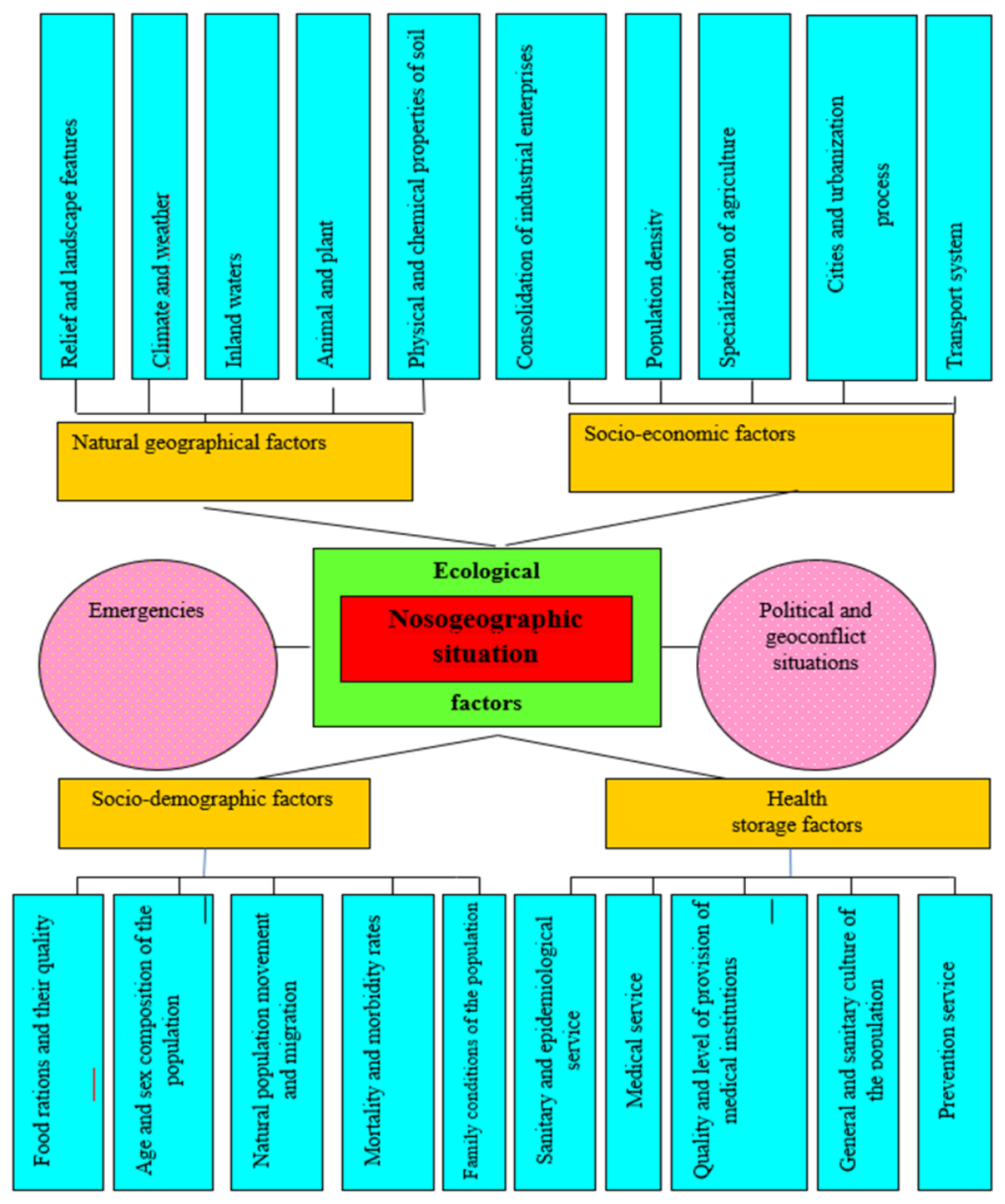

Figure 1. Factors influencing the nosogeographic situation

Nosogeographic complexes or nosogeographic complexes are a territorial combination of various diseases that occur under the influence of certain natural geographical and socio-economic, social environments (space). Such complexes are usually associated with natural geographical and economic landscapes as well as a specific socio-geographic environment (Komilova, 2021).

It should be noted that in the analysis of the medical geographical location, nosogeographic situation in the regions, it is advisable to pay special attention to the health of mothers and children living in these areas (Layuk et al. 2021). After all, maternal and child health is the main indicator of the nosogeographic status of each region, district, or medical geographical area (DeVerteuil, 2015). Therefore, the authors tried to systematize the factors that affect the health of mothers and children. This system will serve as a program to achieve sustainable development of the country - the health of the next generation (Liu et al., 2016). It is known that environmental factors can include fresh air, clean water, environmentally friendly food, education, physical activity, drinking, smoking, etc. should not be less than a year (Figure 2). The influence of family members, neighbors, and neighbors also play an important role in maternal and child health (Komilova, 2010; 
Widana et al., 2021). It should be noted that if raise the culture of the population to a high level, will achieve the birth of healthy children from healthy mothers. This will serve as a basis for the next generation to be healthy (Nurcahyo et al., 2021). Continuous environmental education should be conducted in the family, kindergarten, school, lyceum, college, university, and the general public (Figure 3).

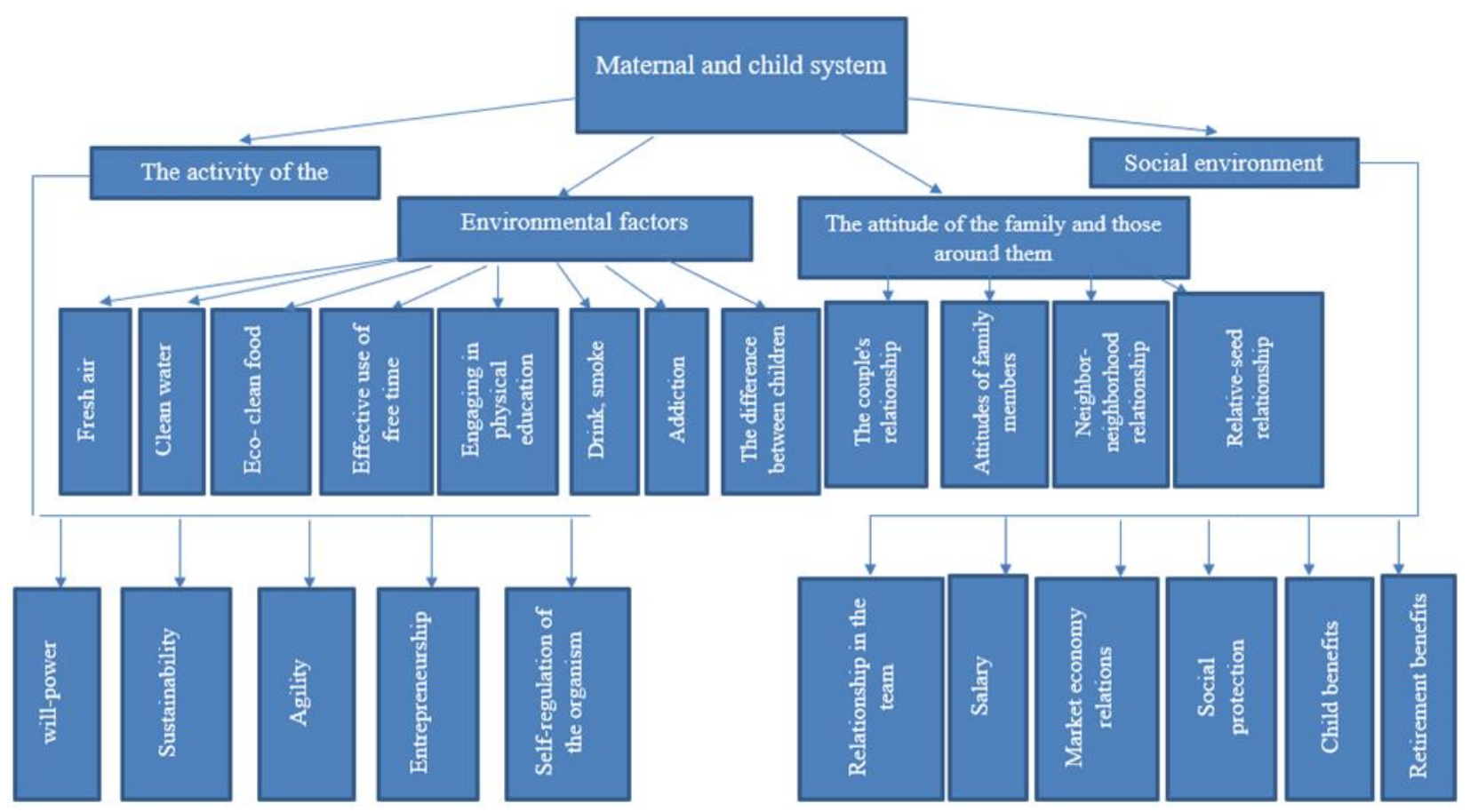

Figure 2. Scheme (system) showing the factors affecting maternal and child health

Komilova, N. K., Rakhimova, T., Allaberdiev, R. K., Mirzaeva, G. S., \& Egamberdiyeva, U. T. (2021). Ecological situation: the role of education and spirituality in improving health of population. International Journal of Health Sciences, 5(3), 302-312. https://doi.org/10.53730/ijhs.v5n3.1512 


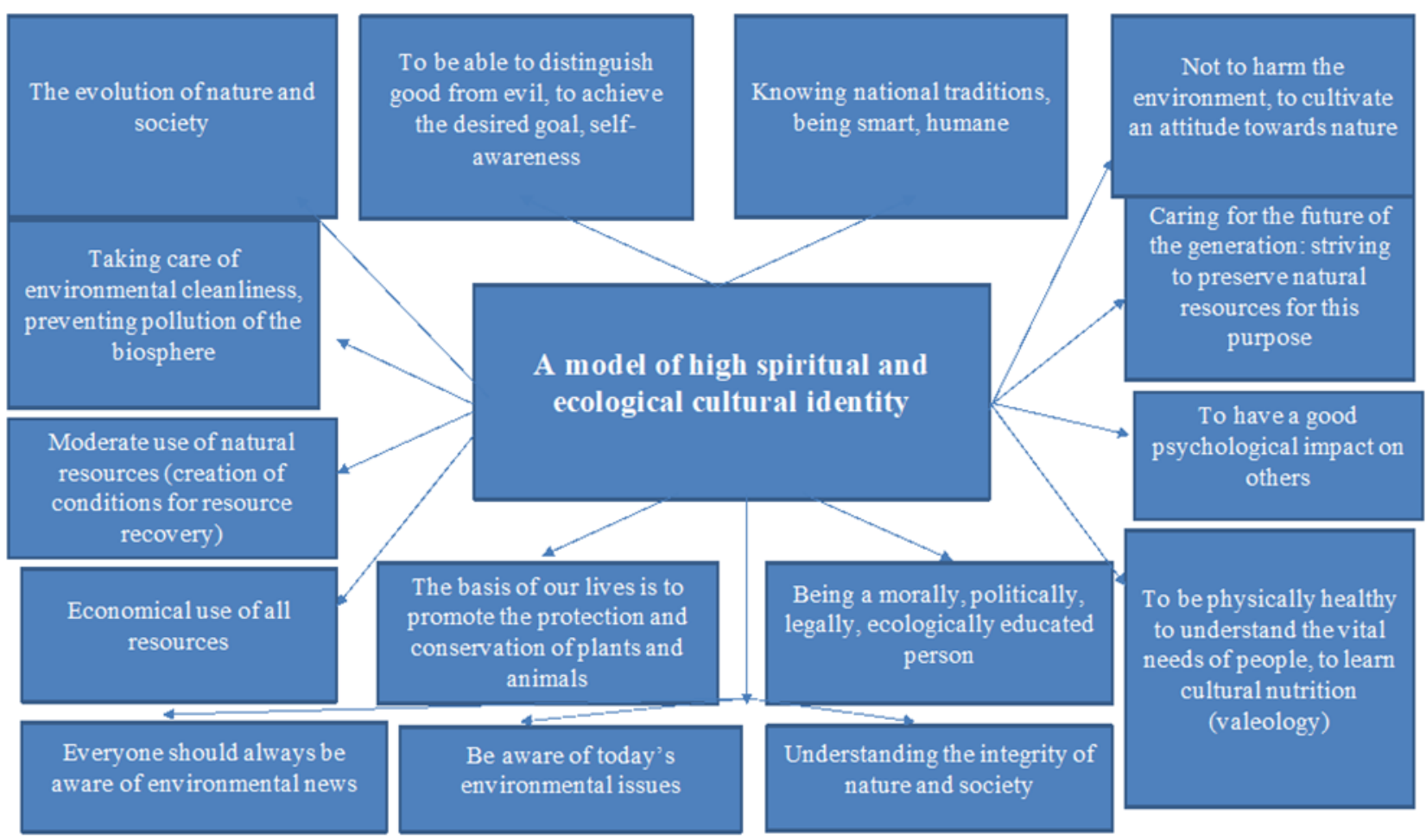

Figure 3. A model of high spiritual and ecological cultural identity

Behavioral culture also has a major impact on health. Also, by raising the culture of communication among the population it is possible to create a positive psychological environment.

\section{Conclusion}

It should be noted that to reduce the negative impact of the environment on human health, it is necessary to:

a) For a healthy environment, pollutants in the air should not exceed the allowable amount.

b) The use of trees, shrubs, and lawns in the formation of a sanitary zone $(1000,500,300$ meters) around the industrial enterprises.

c) Transition to safe modes of transport.

d) Wastewater is treated in various ways and added to water bodies.

e) Training of highly spiritual and ecologically cultured personnel-improvement of the ecological condition of the environment while protecting nature.

It is also advisable to take the necessary measures to combat climate change in connection with the improvement of the environmental situation. It is advisable to focus on the following:

a) Development of a program for adapting the healthcare system of Uzbekistan to global warming, including making the necessary changes to medical education programs.

b) Urban planning aimed at reducing the number of heat islands, improving the built-up urban environment, expanding green areas (taking into account the use of the latest technologies for saving water), switching to electric public transport (electric buses, electric taxis), modern ventilation technologies.

c) Continuation of the process of afforestation of the dried-up bottom of the Aral Sea, an increase in the flow of Amudarya water into the Aral Sea for watering the delta, and - with the successful completion 
of programs for the modernization of the irrigation system and measures to save water consumption in other sectors of the economy - with the aim of partial restoration of sea level, reduction of salt and dust production, improvement of public health northern regions of Karakalpakstan, restoration of fish farming and fur farming.

d) Improving the awareness of people about a healthy lifestyle, quality nutrition, and hygiene, about the necessary precautions taking into account the conditions of predicted climatic changes, warnings about potentially unfavorable weather conditions.

e) Hanging the mode of work and study (if possible, taking into account the need to ensure continuous production of electricity, transport, etc.) at enterprises and institutions during periods of summer heatwaves and - in some years - days with extremely low temperatures.

f) Provision of educational institutions of all levels, government agencies, and enterprises with splitsystems (winter-summer air conditioners); the establishment in educational institutions, enterprises, and institutions of an autonomous power supply system on solar batteries to prevent the growth of greenhouse gas emissions due to an increase in electricity consumption.

g) Modernization of water supply systems to provide $100 \%$ of the population of Uzbekistan with clean drinking water.

h) Improving the spatial organization of the health care system to increase the availability and quality of medical services for residents of settlements of different ranks, including rural ones; At the same time, special attention, including about financing of medical institutions and the provision of specialized medical personnel, should be given to certain categories of patients most vulnerable to climate change - the elderly, people with chronic diseases, lactating mothers and children under 1 year old, and residents of the most vulnerable territories - the flat zone of the country as a whole and, first of all, the estuarine oases of the rivers, from the regions - the Republic of Karakalpakstan and the Khorezm region.

i) In the protection of nature, it is necessary to pay attention to its aspects (health, economic, cultural, educational, aesthetic) among the general public, to carry out advocacy work.

\section{Acknowledgments}

We are grateful to two anonymous reviewers for their valuable comments on the earlier version of this paper.

Komilova, N. K., Rakhimova, T., Allaberdiev, R. K., Mirzaeva, G. S., \& Egamberdiyeva, U. T. (2021). Ecological situation: the role of education and spirituality in improving health of population. International Journal of Health Sciences, 5(3), 302-312. https://doi.org/10.53730/ijhs.v5n3.1512 


\section{References}

Boyle, P., \& Ferlay, J. (2005). Cancer incidence and mortality in Europe, 2004. Annals of oncology, 16(3), 481488. https://doi.org/10.1093/annonc/mdi098

Brown, K. K., Boateng, G. O., Ossom-Williamson, P., \& Haygood, L. (2021). Defining, conceptualizing, and measuring perceived maternal care quality in low-to high-income countries: a scoping review protocol. Systematic reviews, 10(1), 1-8.

Chang, K. T., Hossain, P., Sarker, M., Montagu, D., Chakraborty, N. M., \& Sprockett, A. (2020). Translating international guidelines for use in routine maternal and neonatal healthcare quality measurement. Global health action, 13(1), 1783956.

Clayton, D., \& McKeigue, P. M. (2001). Epidemiological methods for studying genes and environmental factors in complex diseases. The Lancet, 358(9290), 1356-1360. https://doi.org/10.1016/S0140-6736(01)064182

DeVerteuil, G. (2015). Conceptualizing violence for health and medical geography. Social Science \& Medicine, 133, 216-222. https://doi.org/10.1016/j.socscimed.2015.01.018

Falciglia, H. S., Merkel, R. C., Glover, V., Hasselfeld, K. A., \& Brady, W. K. (2020). The mortality of periviable and extremely premature infants and their impact on the overall neonatal mortality rate. Scientific reports, 10(1), 1-7.

Fedakar, R., Gündoğmuş, Ü. N., \& Türkmen, N. (2007). Firearm-related deaths in two industrial cities of Turkey and their province. Legal medicine, 9(1), 14-21. https://doi.org/10.1016/j.legalmed.2006.09.002

Humpel, N., Owen, N., \& Leslie, E. (2002). Environmental factors associated with adults' participation in physical activity: a review. American journal of preventive medicine,22(3), 188-199. https://doi.org/10.1016/S0749-3797(01)00426-3

Komilova, N. K. (2010). Territorial Analysis of Medical-geographycal Conditions and the Problems of Health of the Population of the Republic of Uzbekistan. Journal of Environmental Science and Engineering, 4(12).

Komilova, N. K. (2021). Territorial analysis of medical geographical conditions of Uzbekistan. Current Research in Behavioral Sciences, 2, 100022. https://doi.org/10.1016/j.crbeha.2021.100022

Komilova, N. K., Haydarova, S. A., Xalmirzaev, A. A., Kurbanov, S. B., \& Rajabov, F. T. (2019). Territorial structure of agriculture development in Uzbekistan in terms of economical geography. J. Advanced Res. L. \& Econ., 10, 2364.

Komilova, N. K., Karshibaeva, L. K., Egamberdiyeva, U. T., Abduvalieva, Z. L., \& Allanov, S. Q. (2020). Study of Nozogeographic Situation and Its Study on the Basis of Sociological Survey. Indian Journal of Forensic Medicine \& Toxicology, 14(3).

Komilova, N. K., Ravshanov, A. K., Karshibaeva, L. K., Ishankulova, K. Q., \& Madrahimova, Z. N. (2020). Some Theoretical and Practical Issues of Medical Geographical Research. Indian Journal of Forensic Medicine \& Toxicology, 14(3).

Komilova, N. K., Ravshanov, A. K., Karshibaeva, L. K., Ishankulova, K. Q., \& Madrahimova, Z. N. (2020). Some Theoretical and Practical Issues of Medical Geographical Research. Indian Journal of Forensic Medicine \& Toxicology, 14(3).

Layuk, N., Wahyuni, S., \& Arifuddin, S. (2021). Differences of heparin binding protein levels in preeclampsian and non preeclampsian women. International Journal of Health Sciences, 5(2), 62-70.

Liu, L., Oza, S., Hogan, D., Chu, Y., Perin, J., Zhu, J., ... \& Black, R. E. (2016). Global, regional, and national causes of under-5 mortality in 2000-15: an updated systematic analysis with implications for the Sustainable Development Goals. The Lancet, 388(10063), 3027-3035. https://doi.org/10.1016/S01406736(16)31593-8

McAlister, C., \& Baskett, T. F. (2006). Female education and maternal mortality: a worldwide survey. Journal of obstetrics and gynaecology Canada, 28(11), 983-990. https://doi.org/10.1016/S1701-2163(16)32294-0

McLeod, K. S. (2000). Our sense of Snow: the myth of John Snow in medical geography. Social science \& medicine, 50(7-8), 923-935. https://doi.org/10.1016/S0277-9536(99)00345-7

Nodir, K. U. (2020). Stages and scenarios of health insurance market development in Uzbekistan. International Journal of Psychosocial Rehabilitation, 24(4), 1996-2005.

Nurcahyo, E., Ibrahim R, Kasih, D. P. D., Marwanto, M., \& Ariawan, I. G. K. (2021). Reproductive health protection and the abortion prohibition in Indonesia. International Journal of Health Sciences, 5(2), 99-110.

Palmer, J. (2018). Highlights 2018: health stories in focus. The Lancet, 392(10165), 2673-2690. 
Robinson, J. (2004). Squaring the circle? Some thoughts on the idea of sustainable development. Ecological economics, 48(4), 369-384. https://doi.org/10.1016/j.ecolecon.2003.10.017

Stern, N. (2006). Stern Review: The economics of climate change.

Taylor, R. G., Scanlon, B., Döll, P., Rodell, M., Van Beek, R., Wada, Y., ... \& Treidel, H. (2013). Ground water and climate change. Nature climate change, 3(4), 322-329.

Widana, I.K., Sumetri, N.W., Sutapa, I.K., Suryasa, W. (2021). Anthropometric measures for better cardiovascular and musculoskeletal health. Computer Applications in Engineering Education, 29(3), 550561. https://doi.org/10.1002/cae.22202

Zhu, Z., Li, Z., Bi, X., Han, Z., \& Yu, G. (2013). Response of magnetic properties to heavy metal pollution in dust from three industrial cities in China. Journal of hazardous materials, 246, 189-198. https://doi.org/10.1016/j.jhazmat.2012.12.024

Komilova, N. K., Rakhimova, T., Allaberdiev, R. K., Mirzaeva, G. S., \& Egamberdiyeva, U. T. (2021). Ecological situation: the role of education and spirituality in improving health of population. International Journal of Health Sciences, 5(3), 302-312. https://doi.org/10.53730/ijhs.v5n3.1512 


\section{Biography of Authors}

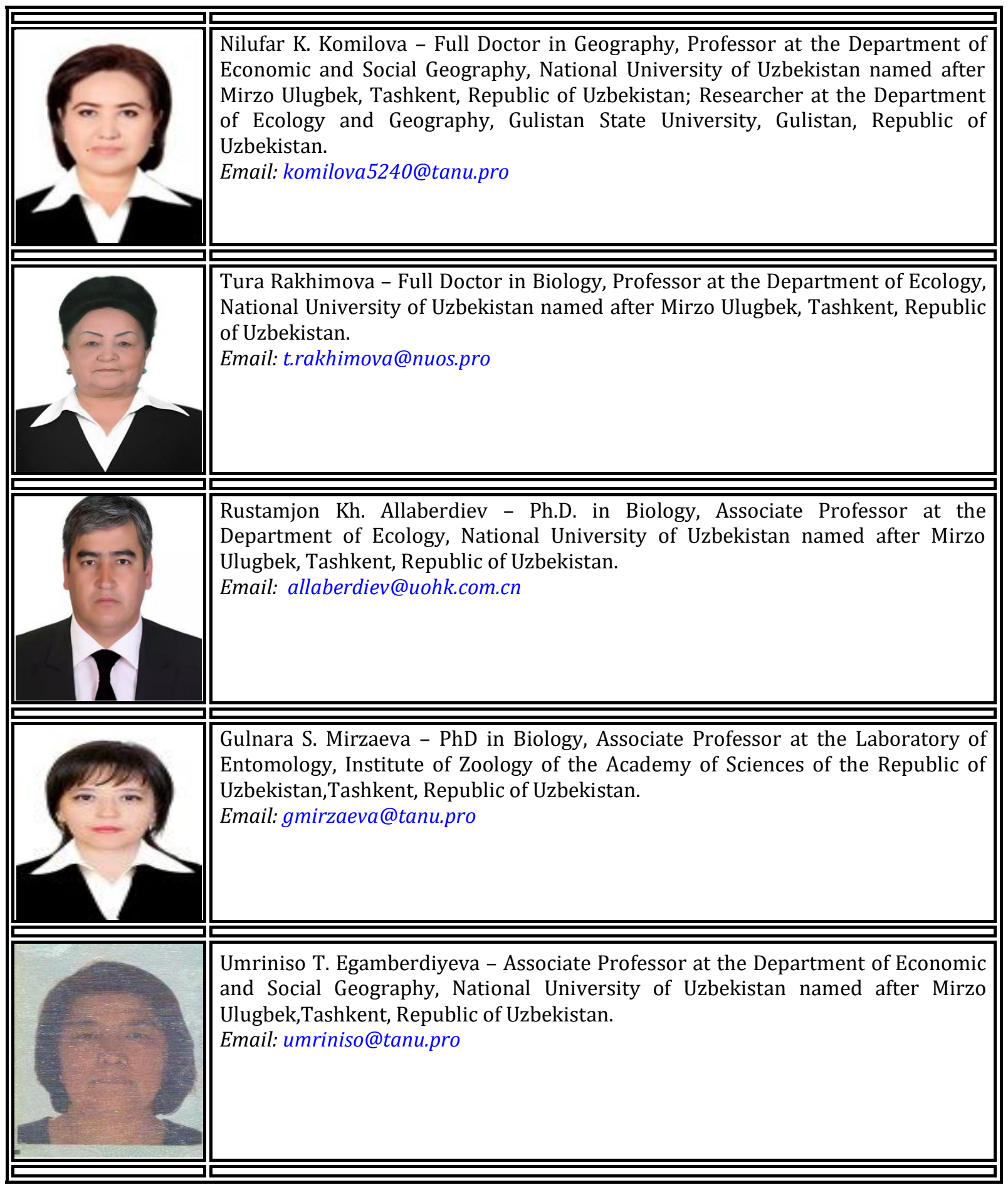

